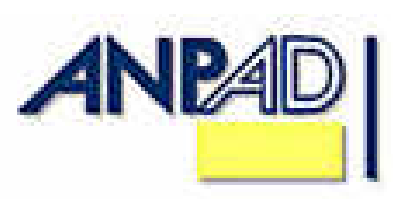

Available online at

http://www.anpad.org.br/bar

\title{
Challenging the Uppsala Internationalization Model: a Contingent Approach to the Internationalization of Services
}

\author{
Jorge Carneiro * \\ E-mail address: jorgemtc@iag.puc-rio.br \\ IAG - Pontifícia Universidade Católica do Rio de Janeiro \\ Rio de Janeiro, RJ, Brazil.
}

\section{Angela da Rocha}

E-mail address: angela@ coppead.ufrj.br

Instituto Coppead de Administração - Universidade Federal do Rio de Janeiro

Rio de Janeiro, RJ, Brazil.

\section{Jorge Ferreira da Silva}

E-mail address: shopshop@iag.puc-rio.br

IAG - Pontifícia Universidade Católica do Rio de Janeiro

Rio de Janeiro, RJ, Brazil.

\begin{abstract}
Some authors have questioned whether the well-known Uppsala internationalization model would be generalizable to services. We take one of the model's assumptions - that firms will follow a gradually increasing resource commitment path in each country - and challenge whether it would hold up under specific service characteristics or particular combinations of environmental variables and service characteristics. We review the literature in search of more appropriate dimensions for the classification of services that would allow for the test of the Uppsala model's assumption. Based on purely conceptual reasoning, supported by previous empirical studies, we propose some hypotheses about how service firms would be expected to behave - in terms of their choice of foreign entry mode - under certain circumstances and what the performance implications would be expected to be. These hypotheses are contrary to the Uppsala model's predictions. This paper is solely conceptual, so the key constructs (environment and service-specific variables) would still require operationalization before the hypotheses can be empirically tested.
\end{abstract}

Key words: firm internationalization; international business; services.

Received 03 February 2008; received in revised form 22 April 2008.

Copyright (C) 2008 Brazilian Administration Review. All rights reserved, including rights for translation. Parts of this work may be quoted without prior knowledge on the condition that the source is identified.

*Corresponding author: Jorge Carneiro

Rua Dezenove de Fevereiro, 127 / 201, Botafogo, Rio de Janeiro, RJ, 22280-030, Brazil. 


\section{INTRODUCTION}

The Uppsala model (Johanson \& Vahlne, 1977, 1990) is one of most frequently cited models in the internationalization literature (c.f. Andersen, 1993; Langhoff, 1997; Oviatt \& McDougall, 1994). The model states that firms will tend to internationalize first to psychically close countries and gradually move to more psychically distant markets. The model also states that, as a firm chooses a new foreign country, it will start from a low resource-commitment mode and only move to higher commitment modes as it gains experiential knowledge in the foreign market.

The model has been tested mainly in manufacturing industries. However, considering the growing importance of services in the world economy, it is questionable whether the model assumptions would also apply to services.

Services are defined as "...deeds, performances, and efforts that provide benefit to customers" (Cloninger, 2000, p. 9). Such a definition is broad enough to cover all types of services, including those embodied in a product offer. Nevertheless, our focus here is on service industries, i.e., those industries whose products are predominantly intangible. We suggest here that the usual categorizations - such as, services vs. goods, services industries boundaries, hard vs. soft services - may not be the best way to approach the particularities of services and their impact on the internationalization path of services firms. Other strategic dimensions of services may help to shed more light on this issue.

By contrasting and integrating the conceptual and empirical literature, this paper advances hypotheses that can help one to test whether the Uppsala internationalization model can properly explain the international expansion of different types of services industries, discussing whether the generic assumption of a gradually increasing commitment path would hold under different combinations of environmental circumstances and service configurations. Such a discussion provides conceptual support for a contingency approach to the internationalisation of services. We contend that the assumption of a gradual commitment path might not hold for service industries, and that the effect of some variables on the foreign entry mode chosen by service firms might depend on the level of other variables.

Moreover, one ought to investigate not only how firms actually behave under a given combination of circumstances (contingencies) - i.e., a descriptive perspective -, but also how they should behave in order to improve their results (in the sense of economic return or financial performance) under a given combination of circumstances (contingencies) - i.e., a normative perspective. In this paper we have focused the discussion on one of the variables used to characterize the internationalization process of firms: the entry mode.

Paraphrasing Brouthers, Brouthers and Werner (1999), the research questions here revolve around the following theme: can the Uppsala internationalization model be used to describe the most commonly selected entry modes for service firms (descriptive power) and can the Uppsala internationalization model also predict the best performing entry modes (normative power)?

Recognizing that (i) theoretical models and empirical research have mostly been based on manufacturing industries, (ii) differences between services and goods may imply differences in internationalization decision-making and processes, (iii) differences across types of services may also have implications for the specific internationalization path followed and the performance results obtained, and (iv) that there may be complex interactions among environmental and service-specific variables, this paper addresses three main objectives:

- Identify relevant services dimensions and characteristics that can help account for differences between the internationalization paths for goods and services in addition to differences across service categories; 
Advance hypotheses to assess the descriptive power of the Uppsala internationalization model, as far as the assumption of a gradually increasing commitment path is concerned;

Advance hypotheses to assess the normative power of the Uppsala internationalization model as far as its (albeit implicit) implications associated with the impact of entry mode on performance are concerned.

In this paper our intention is to advance hypotheses, supported by a conceptual discussion, although we do not actually test them here. The key constructs in the hypotheses (specifically, some environmental and also some service-specific variables) need to be operationalized before data can be properly collected and the hypotheses empirically tested.

The paper is organized as follows. Following this introduction, we briefly present the assumptions of the Uppsala internationalization model and address the foreign entry mode decision. We then discuss differences between goods and services and link them to differences in internationalization patterns. We move on to present typologies of services that highlight some dimensions that might explain differences in internationalization paths across types of services and then review previous empirical studies on the internationalization of services. In the next section we advance testable hypotheses that challenge the assumption of a gradually increasing resource-commitment path of the Uppsala internationalization model - as illustrated by certain service-specific variables and environmental circumstances - and also propose performance implications thereof. Some final remarks and suggestions for future research close the paper.

\section{The UPPSALA InTERNATIONALIZATION MOdel AND Foreign ENTRY MODE DeCISION}

\section{Assumptions of the Uppsala Model}

The Uppsala Internationalization Model (Johanson \& Vahlne, 1977, 1990) was initially developed based on case studies of Swedish manufacturers (Johanson \& Wiedersheim-Paul, 1975) adopting a behavioral perspective (Andersen \& Buvik, 2002; Björkman \& Forsgren, 2000) inspired by the work of Penrose (1959), Cyert and March (1963), and Aharoni (1966). The model asserts that a firm's market knowledge (or lack thereof) would be the driving force of its internationalization path. Market knowledge is seen as a function of psychic distance between home and host countries and the firm's accumulated experience in each given market. The model contends that (i) firms choose new countries for expansion according to their psychic closeness to the host country, moving to more psychically distant countries only as they gain experiential knowledge from past international operations; and (ii) resource commitments in each selected country increase in incremental steps as the firm gains experience in each market.

\section{Foreign Entry Mode Decision}

The foreign entry mode choice includes two basic decisions (Erramilli, 1992). The first decision is whether production should be conducted in the host country or in the home country. So this is a decision about foreign (local) production versus exporting. The second decision relates to who should control production. This comes to a decision between full control, or sole ownership, modes (either sole exporting or wholly-owned FDI) versus shared control modes (e.g., exporting by agents, licensing, franchising, joint ventures).

Hill, Hwang and Kim (1990) proposed three underlying variables that would influence the entry mode decision: level of control desired, amount of resource commitment and dissemination risk (i.e., risk that information may leak and be inadvertently used by a third party, usually a supposedly trustable partner, with the consequent loss of revenues). They considered three general entry modes: 
licensing, joint ventures and wholly-owned subsidiaries. Depending on the level of each variable, different entry modes could be more appropriate, and trade-offs would have to be accepted when choosing one entry mode over another.

It can be reasonably assumed that managers will choose one entry mode over another in expectation of getting a higher risk-adjusted return on investment., i.e., they will choose the highest risk-adjusted return on investment from the feasible set of entry options (Agarwal \& Ramaswamy, 1992). Therefore, higher control would supposedly be chosen if it would expectedly raise returns (e.g., through better management of operations) or reduce risks (e.g., through more decision freedom and responsiveness). Much by the same token, lower commitment would be sought in order to reduce investment (the denominator of the ROI formula). As for the intention to reduce dissemination risk, firms may seek protective action, either by means of contractual and monitoring agreements or, alternatively, by the internalization of foreign activities.

However, classical assumptions of perfect information, symmetry in risk aversion, and rational decision-making - which would tend to lead to some optimal and predictable outcome - may not occur in real circumstances (Bazerman, 2001) and decision-makers tend to suffer from bounded rationality (March \& Simon, 1958). Therefore, it may be interesting to investigate whether firms actually behave as suggested by theoretical considerations and whether those which do actually tend to outperform those which do not.

\section{SERVICES VIS-Ä-VIS GOODS INTERNATIONALIZATION PATTERNS}

\section{Relevance of Services in International Trade}

Services represent a major part of the world GDP and account for a significant share of international trade (Axinn \& Matthyssens, 2002; Dahringer, 1991). Furthermore, the internationalization of services has been growing at a rapid pace (Dunning, 1989; Javalgi, Griffith, \& White, 2003; Mathe \& Perras, 1994). Whereas in the 1970s it represented around $25 \%$ of the world's FDI stock, by the early 2000s it accounted for $60 \%$ of the stock and two-thirds of FDI inflows (United Nations Conference on Trade and Development [UNCTAD], 2004). As for exports, in 2006 world exports of services amounted to around 2.8 trillion US dollars (UNCTAD, 2007), accounting for approximately $19 \%$ of world exports in that year (around 14.9 trillion US dollars, including merchandise and services, $c f$. UNCTAD, 2007) and representing approximately 6\% of world GDP (around 48.5 trillion US dollars in 2006, $c f$. World Bank, 2008). Yet, despite the importance of services in the international economy, most research into the internationalization of firms has focused on manufacturing industries (Axinn \& Matthyssens, 2002; Erramilli, 1992; Javalgi \& White, 2002).

\section{Differences between Goods and Services and across Services}

There are important differences that distinguish services from goods. Services tend to be intangible, heterogeneous, perishable, and their production tends to be inseparable from their delivery and consumption (Grönroos, 1990; Lovelock \& Wright, 2001; Nicolaud, 1989). These differences between goods and services notwithstanding, some services may in several aspects be similar to goods in that their production and consumption may be separable, and heterogeneity and perishability concerns may not be relevant. On the other hand, it would be naïve to consider that all non-separable services would be very similar to one another; in fact, they may differ in relevant strategic dimensions so as to make universal approaches less justifiable. Therefore, an explanation of similarities and differences is crucial for a better understanding of strategic and operational implications (Bouquet, Hebert, \& Delios, 2004; Patterson \& Cicic, 1995). 
Some researchers have suggested that internationalization approaches developed to explain manufacturing firms' foreign expansion might very well apply to service industries (Boddewyn, Halbrich, \& Perry, 1986; Terpstra \& Yu, 1988). Other researchers believe that the factors affecting the internationalization of goods cannot be directly generalizable to services (Ekeledo \& Sivakumar, 1998; Erramilli, 1990; Erramilli \& Rao, 1993; Sanchez-Peinado \& Pla-Barber, 2006; Sharma \& Johanson, 1987). Some have argued that research should draw on other theoretical background besides traditional empirical work on the internationalization of manufacturing firms, providing evidence that the complex nature of services may require the use of novel perspectives (Bouquet, Hebert, \& Delios, 2004; Sanchez-Peinado, Pla-Barber, \& Hébert, 2007).

Johanson and Vahlne (1990) - two of the proponents of the Uppsala model - argued that theoretical approaches to internationalization would not be directly generalizable to services and suggested that differences between manufacturing and service firms would call for a context-specific approach in order to understand internationalization processes of services.

A sequential stages model applied to the service context adapted from the Uppsala model was used by Roberts (1999). The empirical results of the study, however, did not provide support to the proposition of sequential stages in the internationalization of service firms. The conflicting conclusions may be attributed to the fact that relevant control variables and interaction effects, as well as certain service dimensions, were not considered in previous studies.

\section{Typologies of Services}

Similarities and differences between manufacturing and service firms as well as across service industries may be subtle, so that more fine-grained dimensions and categorization guidelines are in fact necessary to explain variation in the internationalization processes followed by service firms and the resulting firm performance.

Several classification schemes for the characterization of services have been proposed in the literature, which seek to highlight relevant dimensions that would distinguish among different services. Typologies, or classification schemes, capture the essence of the relevant characteristics, simplifying the understanding and visualization of complex combinations (Hambrick, 1983). The categories of a typology allow the researcher to include the conjoint impact of distinct combinations of variables, which interact in a complex manner, instead of considering just the independent, direct effects of each variable (Namiki, 1994). Furthermore, a classification scheme is crucial in order to make it possible to arrive at conclusions and generalizations (Clark, Rajaratnam, \& Smith, 1996).

In this discussion we make use of four service typologies extracted from the literature. They were selected because their classificatory dimensions are deemed relevant to the understanding of the contingent approach to internationalization advocated in this paper.

Patterson and Cicic (1995), building on Vandermerwe and Chadwick (1989), proposed a typology based on two dimensions - degree of tangibility and degree of face-to-face contact with the client in service delivery - and two levels for each dimension (Table 1).

Table 1: Vandermerwe and Chadwick's (1989) Services Typology

\begin{tabular}{|c|c|c|c|}
\hline \multirow{4}{*}{ 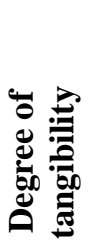 } & \multirow[b]{3}{*}{ Pure services } & \multicolumn{2}{|c|}{ Degree of face-to-face contact with client in service delivery } \\
\hline & & Low & High \\
\hline & & Location-free professional services & $\begin{array}{l}\text { Location-bound customized } \\
\text { projects }\end{array}$ \\
\hline & $\begin{array}{l}\text { Services bundled } \\
\text { with goods }\end{array}$ & Standardized service packages & Value-added customized services \\
\hline
\end{tabular}


Location-free professional services. In this type of service, professionals may stay in their own countries most of the time, traveling to the client's country only to identify needs, sign a contract, and present results. Thus, physical facilities are not needed in the country of destination. Since contacts with the client are not very intense, such services tend to be more standardized. Examples are executive recruitment, transportation, finance and insurance, IT and architectural projects.

. Location-bound customized projects. Such services require closer and more frequent contact with clients in order to better serve them or to adapt the service to their needs. They tend to be long-range services and demand the presence of a professional in the client's country. Technical consulting in general (management, engineering, human resource development), legal assistance, or an advertising agency fit into this category.

- Standardized service packages. These services are usually associated with physical goods and are more likely to be exported in a traditional way. Examples are software development, configuration and maintenance of electronic equipment, and distance education.

- Value-added customized services. These services demand a high degree of interaction with the client, thus adding considerable value to the basic offer. Examples are on-site technical training and support and management of large facilities.

Lovelock and Yip (1996) proposed a similar taxonomy, based on the nature of the process (tangible or intangible) and on the degree of involvement of the client (physical presence or absence during the rendering of the service) (see Table 2).

Table 2: Lovelock and Yip's (1996) Services Typology

\begin{tabular}{|c|c|c|c|}
\hline & \multicolumn{2}{|c|}{ Degree of involvement of the client } \\
\hline & & Low (physically absent) & High (physically present) \\
\hline \multirow{2}{*}{ 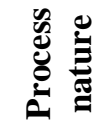 } & Tangible & Possession-processing services & People-processing services \\
\hline & Intangible & Information-based services & \\
\hline
\end{tabular}

Possession-processing services. These services involve tangible actions that increase the value of the object. Some examples are freight transport, warehousing, equipment installation and maintenance, car repair, facilities security, veterinary services, laundry services and disposal of industrial waste. The object must be physically involved, but the client need not be. Depending on the service, the factory could be fixed or mobile. It will be fixed when the service must be rendered in a specific location a number of times, and mobile when technology allows the service to be rendered at a distance.

People-processing services. These services are tangible actions to clients who must be physically or mentally present. Clients become part of the production process, which is simultaneous to the consumption. Examples are passenger transportation, medical assistance, restaurants, hotels, and museums. The client goes to the location where the service is rendered (a plane, a hospital or a restaurant, for example), or the service provider goes to the client (medical assistance). In either case, the service provider needs to maintain physical facilities near the location of interaction with the client.

. Information-based services. These services involve the collection, treatment, interpretation and transmission of information, such as accounting, banking and insurance, training, legal assistance, news production and broadcasting, and marketing research. The physical involvement of the client is usually low and electronic channels can be used for delivering the service to any part of the world. Physical presence can be limited to contact equipment and telecommunications infrastructure, permitting remote access. 
Clark, Rajaratnam and Smith (1996) proposed a classification scheme based on who or what crosses the border (Table 3).

Table 3: Clark, Rajaratnam, and Smith's (1996) Services Typology

\begin{tabular}{|c|c|c|c|c|}
\cline { 2 - 5 } \multicolumn{1}{c|}{} & \multicolumn{4}{c|}{ Types of international services } \\
\cline { 2 - 5 } \multicolumn{1}{c|}{} & Contact-based & Vehicle-based & Asset-based & Object-based \\
\hline Crosses the or what & People & $\begin{array}{c}\text { Electromagnetic } \\
\text { signals }\end{array}$ & $\begin{array}{c}\text { Capital, organizing } \\
\text { principles }\end{array}$ & Objects \\
\hline
\end{tabular}

Contact-based services. In this type of service, people (either the provider or the consumer) move to other countries. Examples are consulting and tourism services.

. Vehicle-based services. This type of service is rendered by vehicles such as satellites, cables, and antennas; electromagnetic signals cross the border. Examples are TV programs, telephone calls, news broadcasts, and data transferred via the Internet.

- Asset-based services. Physical assets are necessary in the host country for the service to be provided. Some examples are banks, hotels, hospitals or traditional retail chains.

- Object-based services. Objects impregnated with services cross the border, such as DVDs with movies, software recorded in electronic media, air or train transportation, and maintenance contracts together with parts supplied.

Lovelock (1983) proposed several services typologies, one of which categorizes services according to the degree of standardization vs. adaptation. There are two dimensions of customization: the degree of flexibility allowed by the characteristics of service production and delivery; and the level of interference of the service provider in the configuration of the service (Table 4).

Table 4: Lovelock's (1983) Services Typology

\begin{tabular}{|c|c|c|c|}
\cline { 2 - 4 } \multicolumn{2}{c|}{} & \multicolumn{2}{c|}{ Extent to which service characteristics are customized } \\
\cline { 2 - 4 } \multicolumn{2}{c|}{} & \multicolumn{2}{c|}{ Low } \\
\hline \\
\hline
\end{tabular}

- Standardized services with little influence by contact personnel. Some services are very standardized. For example, train transportation has timetables and fixed routes, and many restaurants offer little flexibility of their menu.

- Customized services with little influence by contact personnel. Telephone services allow the client to choose a series of items beyond the basics, such as follow me, an alarm clock, or a detailed bill. The same happens with banks or good hotels, which offer an extensive list of services clients can choose from. Contact personnel, however, have little freedom to change service characteristics beyond the pre-defined options.

- Standardized services with considerable influence by contact personnel. Some services allow each provider to leave its particular mark, even though every client receives a service very similar to what 
other clients receive in each particular occasion of service rendering. For example, each teacher chooses his/her own material and pedagogic methods, which differentiate him/her from other teachers. Each of his/her students, however, receives basically the same type of class.

. Customized services with considerable influence by contact personnel. These imply a high degree of customization and, at the same time, demand that contact personnel have considerable discretion over the service offered to each client. Clients do not play a passive role. Such services require that contact personnel achieve a high degree of training and capacity to understand and satisfy clients' needs. Some examples are medical treatment, legal and tax assistance, architectural design, and hairdressing and make-up services.

\section{VARIAbles AfFeCtING THE INTERNATIONALIZATION OF SERVICES}

Erramilli (1990) examined variation in entry mode choice across service industries and concluded that hard services firms (where production can be decoupled from consumption) tend to choose similar entry modes as would product firms, but soft services firms (where production and consumption occur simultaneously) tend to use more integrated (higher-control) entry modes. Moreover, as the need for customization becomes stronger, service firms would tend to resort to more integrated entry modes. Ekeledo and Sivakumar (1998) supported Erramilli's (1990) generic argument, indicating that entry mode decisions differ significantly between hard and soft services, but that hard services showed similarities with goods.

Other researchers studied the extent to which the classic dimensions of services (intangibility, simultaneity, heterogeneity, and perishability) affected the internationalization of services. Erramilli and Rao (1990) concluded that the separability aspect of services moderated the relationship between motives to internationalize (client-following vs. market-seeking) and entry mode selection. Bouquet, Hebert and Delios (2004) and Sanchez-Peinado and Pla-Barber (2006) also found empirical evidence that separability had an influence on the choice of entry mode. Cloninger (2000) determined that services that were less intangible, less perishable and less simultaneous had a higher probability to internationalize, and that intangibility was a predictor of entry mode (more tangible services were associated to a higher-control entry mode).

Erramilli (1991) investigated the impact of a service firm's international experience on the type of foreign country chosen and the mode of entry selected. He found that, in support of generally accepted internationalization theory, as service firms become more experienced (both in length - number of years - and scope - geographical spread), they tend to expand to more psychically distant countries. However, contrary to what he expected, he found a curvilinear ( $\mathbf{U}$-shaped) relationship between experience and the degree of control of the entry mode selected - i.e., less experienced service firms tended to prefer higher-control modes, moving to lower-control modes as they gained moderate experience, and moving again to higher-control modes as they reached higher levels of experience. Sanchez-Peinado and Pla-Barber (2006) found that cultural distance did not significantly influence the choice of entry mode by service firms. They found, nevertheless, a negative relationship between international experience and the choice of higher-control entry modes, partially supporting Erramilli's (1991) results and contradicting Uppsala's predictions.

The influence of external and internal factors on service firms' choice of entry mode was studied by Erramilli (1992). He concluded that service firms tended to use more integrated (higher-control) entry modes the larger the foreign market size and the greater the unavailability of host country suitable partners and the firm's corporate policy on keeping control of operations. On the other hand, service firms tended to use less integrated (lower-control) entry modes the greater the restriction on foreign ownership, the firm's aversion to environmental risk, the desire to get rapidly established, and the constraints on internal resources. Sanchez-Peinado and Pla-Barber (2006) found that market potential significantly impacted entry mode choice: firms tended to choose higher-control entry modes when 
entering markets with higher growth rates. However, these authors did not find support for the impact of country risk on entry mode.

As to the impact of external uncertainty, Erramilli and D'Souza (1995) concluded that the probability of service firms employing FDI modes tended to decrease as external uncertainty increased, but only when capital intensity was high. Furthermore, the inhibiting impact of external uncertainty on FDI mode choice was shown to be stronger with smaller firms, especially when they moved from a country characterized by low uncertainty to another with high uncertainty. However, contrary to expectations, they found that for larger firms an increase in external uncertainty seemed to increase the probability of choosing FDI (i.e., higher-control) modes.

Earlier works have approached and operationalized services from general and broad categories, for example, hard (separable) vs. soft (non-separable), or from the perspective of the four classic dimensions related to the nature of services. Other have used various service industries, and later speculated on which characteristics of these industries seemed to lie behind differences in the choice of entry mode.

The complexity of services, however, has led some authors to study the internationalization process from the perspective of one single service industry, thus avoiding the issue of differences across industries. For example, specific studies have been done on the internationalization of business services (O'Farrell, Wood, \& Zheng, 1996; Roberts, 1999), engineering consulting (Baark, 1999; Coviello \& Martin, 1999), financial services (Álavarez-Gil, Cardone-Riportella, Lado-Cousté, \& Samartín-Sáenz, 2003; Cardone-Riportella, Alvarez-Gil, Lado-Couste, \& Sasi, 2003; Katrishen \& Scordis, 1998), hospitality (Alexander \& Lockwood, 1996; Dunning \& Kundu, 1995), professional services (Skaates, Tikkanen, \& Alajoutsijärvi, 2003), and software (Ojala \& Tyrväinen, 2007).

\section{Proposition OF TESTABLE HYPOTHESES}

It is reasonable to assume that firms, all else being equal, will prefer less risk to more risk. This would justify the preference to expand to psychically-close countries and to commit resources in a gradual manner. However, some services may exhibit certain characteristics that either make psychic distance less relevant or preclude a gradually-increasing resource commitment path, thereby violating two basic assumptions of the Uppsala Internationalization model.

For example, location-bound customized projects, contact-based services, people-processing services and customized services with considerable influence by contact personnel, tend to skip low involvement entry modes because: (i) they require the physical presence of the service provider, thus ruling out exporting; (ii) they need to be offered on an integral basis from the outset due to simultaneity of production, delivery and consumption; (iii) they are difficult to standardize, which makes licensing less possible; and (iv) they may demand more control and involvement (and therefore a higher resource commitment) owing to the need for quality and image control as well as responsiveness and failure recovering.

Furthermore, service firms may be more prone, vis-à-vis manufacturing firms, to choosing higher commitment modes not only because some services require a smaller amount of financial resources (e.g., an office vis-à-vis a factory), but also because they may entail less risk since resources committed tend to be more flexible and more easily transferable to other locations and alternative applications (e.g., personal and managerial skills vis-à-vis factory or other physical facilities).

As for the relevance of psychic distance, some services may not be affected in the same way as others. Some (though not all) less tangible services may be more prone to a client-following pattern (e.g., consulting, advisory or auditing services); in some object-based (e.g., fast-food) as well as in some people-processing services (e.g., hotels chains) clients may value standardization across 
countries; standardized services with little influence by contact personnel are more immune to cultural differences since they are less dependent on personal interaction. All these examples make it clear that psychic distance may not universally and homogenously affect all types of services.

The picture just painted gets more complicated, though, since entry mode decisions can have multiple consequences. For example, given that higher control may help reduce some risks (e.g., dissemination risk, $c f$. Hill, Hwang, \& Kim, 1990), but at the same time may imply an increase in other types of risk (due to the raising of exit barriers or the likelihood of local government retaliation), it might be necessary to include in the analysis additional interacting and contingency variables (both external as well as internal to the firm) instead of hoping for a universal recommendation.

Much by the same line of reasoning, the literature often seems to offer contradictory recommendations, i.e., given the level of some environmental variable, a high (low) control entry mode would be recommended, but the level of a different environmental (or firm- or service-specific for that matter) variable might recommend a different entry mode. Therefore, certain trade-offs have to be accepted (Anderson \& Gatignon, 1986) in order to maximize the expected risk-adjusted return on investment. The proper consideration of the interaction between pairs of variables may help resolve some of the apparent conflicts.

In fact, multiple interactions are expected to occur, but they may be difficult to model and test. Resorting to a bivariate approach may be a satisfactory compromise between a totally reductionist perspective versus a totally holistic perspective (Venkatraman \& Prescott, 1990).

\section{Choice of the Explanatory Variables}

It is worth noting that the proponents of the Uppsala Internationalization Model themselves stressed that its predictive power value (in terms of the description of the internationalization paths to be followed by firms) might be limited. However, they were thinking of some specific explanatory variables that had been left out of the model, such as "the decision style of the decision-maker himself and, to a certain extent, the specific properties of various decision situations" (Johanson \& Vahlne, 1977, pp. 32-33).

We fully agree with them and have, in fact, gone a step further by choosing a particular set of explanatory variables - i.e., specific dimensions and characteristics of services and their interplay with specific environment circumstances - and discussed how some particular combinations of environment and service configurations might affect the internationalization path chosen and, as a matter of fact, challenge the assumption of a gradually increasing commitment path.

Several explanatory variables have been suggested which are supposed to have an influence in the internationalization processes of services. For example: environment-related factors (legal requirements and restrictions, market potential, political and economic risk, degree of external uncertainty, psychic distance, existence of capable potential licensees); firm-related factors (a firm's possession of financial and managerial resources (usually related to firm size) or other complementary resources, market knowledge, motivation to go international, advantages of global coordination of activities); and service-specific factors (capital intensity, degree of investment irreversibility, degree of tangibility, degree of inseparability, degree of personal interaction, extent of customization requirements, need for quality assurance or image control, need for local assistance and responsiveness, transportation costs, extent of knowledge transferability, stage of the technology life cycle, level of information asymmetry between would-be licensor and potential licensees, contractual risks, dissemination risks) (Anderson \& Gatignon, 1986; Cicic, Patterson, \& Shoham, 1999; Ekeledo \& Sivakumar, 1998; Erramilli, 1992; Nicolaud, 1989; Sanchez-Peinado, Pla-Barber, \& Hébert, 2007).

This is a long list of variables, which could be expanded even further. Nevertheless, in order to keep the complexity and size of this paper manageable, we decided to circumscribe our discussion to some environment-related and some service-specific variables, leaving firm-related variables out of our conceptual framework. 
We chose particular variables to question some of the Uppsala model's assumptions:

environment-related: environmental uncertainty and psychic distance; and

service-specific: capital intensity, level of customization and closeness of contact, need for quality assurance (control), need for image control, degree of tangibility, degree of face-to-face contact with client in service delivery, and level of standardization

\section{Impact of Environmental Uncertainty and Capital Intensity}

Erramilli and D'Souza (1995) found that service firms tend to use FDI as their preferred entry mode (the authors investigated only the first entry movement into a new country) when external uncertainty is high and at the same time capital intensity is low. They explain this unexpected finding by resorting to arguments first advanced by Klein and Roth (1990): "FDI modes allow firms to be closer to their markets and, in markets characterized by high volatility, proximity gives them the ability to identify fluctuations in the local market more quickly and respond to them faster" (Erramilli \& D'Souza, 1995, p. 57).

Since many services demand very little capital, firms expanding to highly uncertain environments might tend to internalize their activities and produce the service locally even if it could have been exported or, in some cases, licensed. This might be the case with some location-free professional services (e.g., executive recruitment, market research packages, architectural projects) and also possession-processing services (although, in this case, capital intensity may not be so low) even if technology would have allowed the service to be rendered from a distant place (e.g. diagnostic and support services). In fact, a preference for high-control may also be expected to be found when external uncertainty is low: low perceived risk would encourage firms to commit more resources (specially if their total amount is low) in order to keep control. Intermediate levels of uncertainty might prompt service firms to partner with some local company in order to share part of the risk. From this reasoning, the following two hypotheses are suggested (the suffixes $\mathbf{D}$ and $\mathbf{N}$ mean, respectively, a hypothesis to test the descriptive power and a hypothesis to test the normative power):

$\mathrm{H}_{\mathrm{D} 1}$ : For services that demand low capital intensity, there will be a U-shaped relationship between environmental uncertainty and the preference for higher control (usually higher commitment) modes: at low levels as well as at high levels of (perceived) environmental uncertainty, the proportion of low-capital service firms that will choose higher-control modes will be greater than the respective proportion when environmental uncertainty is moderate.

$\mathrm{H}_{\mathrm{N} 1}$ : Low-capital service firms that choose a higher-control entry mode in countries where environmental uncertainty is high, as well as in countries where environmental uncertainty is low, will on average outperform those that choose a lower-control entry mode (supposedly due to higher revenues from responsiveness in the first case and to lower negotiation and monitoring costs in the second case).

\section{Impact of Level of Customization and Closeness of Contact, Need for Quality Assurance, and Need for Image Control}

International operations may face some types of contractual risks (Agarwal \& Ramaswami, 1992). In the case of services, such risks may be of a particular nature:

Dissemination risk and free-riding potential, i.e., risk that knowledge will be dissipated and may be expropriated by partner or licensee - A partner might learn by doing and then become a competitor, especially because most services cannot be patented. 
- Obstacles and costs to appropriately transfer knowledge (to partners or licensees) as well as to sign, monitor and enforce contracts - When the service demands a case by case solution for each client, it may be difficult to codify the routines and transfer knowledge.

. Inadequate quality or image control - For some services, preserving the reputation of the service provider is essential for success, especially when the results are difficult to evaluate objectively (as is the case with medical, legal and consultancy services) and, as a consequence, confidence in the service provider has significant impact on how much a client may be willing to pay. In these cases, it might be worthwhile to internalize activities (higher control), lest a licensee might undermine the firm's reputation.

In case of high contractual risks, service firms would be expected to choose full-control entry modes (e.g., sole exporting, if possible, or FDI) over licensing or joint ventures. Location-bound customized projects, value-added customized services, contact-based services, standardized services with considerable influence by contact personnel, and customized services with considerable influence by contact personnel involve more tacit, and thus less codifiable, knowledge, so they are less prone to licensing and it would be difficult to properly write and monitor a contract specifying how such services should be rendered. For these reasons it is hypothesized that service firms that offer such services would rather choose higher-control entry modes since the very beginning. If the service has to be provided locally this higher-control would also entail higher-commitment (because of physical facilities) and, as such, skipping some earlier stages of gradual commitment.

$\mathrm{H}_{\mathrm{D} 2}$ : Firms that provide services that (i) demand significant customization and close contact with clients, or (ii) demand rigorous quality assurance (e.g., by highly skilled professionals), or (iii) depend on a strong image or reputation will tend to resort to full-control (higher-commitment) entry modes (due to own personnel and local facilities) from the outset rather than following a sequential path from exporting through licensing, and eventually FDI.

$\mathrm{H}_{\mathrm{N} 2}$ : Firms that provide services that (i) demand significant customization and close contact with clients or (ii) demand rigorous quality assurance or that (iii) depend on a strong image or reputation will on average reach higher performance results if they choose higher-control entry modes than if they choose lower-control entry modes.

\section{Impact of Degree of Tangibility and of face-to-face Contact with Client in Service Delivery}

Firms that offer location-free professional services or rather standardized service packages (recall Vandermerwe \& Chadwick's (1989) typology), where interaction and involvement with the client is done on just a few discrete occasions and production can be decoupled from delivery (e.g., executive recruitment, finance and insurance, IT, and architectural projects), specially if bundled with physical goods (software development, configuration and monitoring of electronic equipment), are likely to find that the costs of having local facilities and personnel outweigh the (infrequent) traveling and transportation costs. Moreover, customers will probably not value responsiveness and extensive adaptation enough as to be willing to pay more for it. This means that services such as these will tend to be exported and, in fact, may never move on to higher-commitment modes. However, as a relatively high number of customers is gained in a given host country, the costs of keeping local facilities and personnel may be less than the traveling and transportation costs that would otherwise be needed. At this stage, local production may be a better mode as compared to exporting. This means that the internationalization path would probably not follow a smooth and gradual increase in commitment and involvement, but would in fact present a step function pattern.

$\mathrm{H}_{\mathrm{D} 3}$ : Firms that provide location-free professional services or standardized service packages will tend to export them rather than produce them locally in the target countries. However, as the number of clients in a given host country becomes high, firms will tend to produce such services locally rather than export them. 
$\mathrm{H}_{\mathrm{N} 3}$ : Firms that provide location-free professional services or standardized service packages will achieve higher performance if they export their services rather than offer them locally in the target countries. However, as the number of clients in a given host country becomes high, performance will be higher for firms that produce such services locally as compared to firms that export them.

\section{Interaction between Level of Service Standardization, Capital Intensity and Psychic Distance}

As for standardized services, the type of knowledge is usually easier to transfer to partners or licensees. However, when psychic distance is high (e.g., differences in culture, tastes, business practices, legal environment, infrastructure), it may be necessary to conduct adaptations to the service package, although no customer-by-customer customization is necessary.

The specific modifications required may not always be clear from the start. Therefore, a service firm may choose a higher-control entry mode, whereby it would be able to introduce the necessary adaptations in a "learn by doing" fashion. Once satisfied with the adapted service package, it may decide to license it to third parties. Therefore, in the case of high (perceived) psychic distance, an inverted (to the Uppsala model's expectations) sequence of expansion might be observed, from higherto lower-control modes.

On the other hand, if psychic distance is perceived to be small, service firms may not be averse to resorting to higher-control (usually higher-commitment) modes, especially in the case of services that demand low capital requirements and, as such, lower perceived risks.

Given the fact that the low (in an absolute sense) amount of financial capital commitment and the perceived psychic closeness may lead to less perceived risk, firms may prefer a full-control entry mode (e.g.: sole exporting, if possible, or FDI). When psychic distance is moderate, firms may tend to resort to local partners, either by licensing, if the service routines can be codifiable, or by joint venturing. In both cases, the partner could contribute with specific knowledge and business connections in the local market. Such contributions by a partner would also be important when psychic distance is high, but the partner might not be able to fully understand the implications of service adaptations, leading firms to favor internalization (full control) in their initial steps in a new market.

$\mathrm{H}_{\mathrm{D} 4 \mathrm{a}}$ : For standardized services that demand low capital intensity, the relationship between the initial entry mode and psychic distance will be $\mathbf{U}$-shaped, with higher-control modes being preferred at both low and high (perceived) psychic distance and shared-controls modes (e.g., licensing or joint venturing) preferred at moderate (perceived) psychic distance.

$\mathrm{H}_{\mathrm{D} 4 \mathrm{~b}}$ : When internationalizing to a psychically distant country, firms that offer standardized services of high capital intensity will tend to follow a reverse commitment path, first choosing higher-control entry modes and later on migrating to lower-control entry modes as the expansion in the respective country moves on.

$\mathrm{H}_{\mathrm{N} 4 \mathrm{a}}$ : For the expansion of standardized services that demand low capital intensity into psychically distant countries, firms that choose higher-control modes for the initial market entry will on average outperform those that choose lower-control modes.

$\mathrm{H}_{\mathrm{N} 4 \mathrm{~b}}$ : For the expansion of standardized services of high capital intensity into psychically distant countries, firms that follow a reverse commitment path (i.e., from higher- to lower-control entry modes) will on average outperform those that follow a gradually increasing commitment path. 


\section{Challenges to the Uppsala Internationalization Model}

We now provide the reader with a brief recap of the hypotheses presented above and explain exactly where they would challenge the Uppsala model. Table 5 presents the variables used in each hypothesis.

Table 5: Variables Used in the Hypotheses

\begin{tabular}{|l|l|l|l|}
\hline & \multicolumn{1}{|c|}{ Independent variables } & \multicolumn{1}{c|}{ Dependent variables } \\
\hline $\mathbf{H}_{\text {D1 }}$ & \multicolumn{1}{|c|}{ Environment } & \multicolumn{1}{c|}{ Service-specific } & \\
\hline $\mathbf{H}_{\text {D2 }}$ & & - capital intensity & $\begin{array}{l}\text { intensity of control } \\
\text { (commitment) }\end{array}$ \\
\hline $\mathbf{H}_{\text {D3 }}$ & & $\begin{array}{l}\text { - level of customization and } \\
\text { closeness of contact } \\
\text { - need for quality assurance } \\
\text { (control) }\end{array}$ & $\begin{array}{l}\text { intensity of control } \\
\text { (commitment) }\end{array}$ \\
\hline $\mathbf{H}_{\text {D4a }}$ & psychic distance & $\begin{array}{l}\text { - degree of tangibility } \\
\text { - degree of face-to-face contact } \\
\text { with client in service delivery }\end{array}$ & $\begin{array}{l}\text { location of production (as it } \\
\text { associated with resource } \\
\text { commitment) }\end{array}$ \\
\hline $\mathbf{H}_{\text {D4b }}$ & psychic distance & $\begin{array}{l}\text { - level of standardization } \\
\text { - capital intensity }\end{array}$ & $\begin{array}{l}\text { intensity of control } \\
\text { (commitment) }\end{array}$ \\
\hline
\end{tabular}

What would the Uppsala model predict in each case?

Hypothesis $\mathrm{H}_{\mathrm{D} 1}$ - The Uppsala model is a risk-aversion or risk-avoidance model (Bjorkman \& Forsgren, 2000), which contends that firms would only move to higher commitment modes as they gained experience in a given foreign market (or other foreign markets also, if this experience could be transferred). Whether or not the level of environmental uncertainty would affect the rate of knowledge gained by the firms is not explicitly addressed by the model. This silence notwithstanding, the fact is that a preference for higher commitment from the beginning (despite of being a possible way to deal with risk) goes against the assumptions of the Uppsala model.

Hypothesis $\mathrm{H}_{\mathrm{D} 2}$ - The Uppsala model does not address the impact of the characteristics of specific services (or goods, for that matter) on the internationalization path. Nonetheless, a preference for higher commitment entry modes from the beginning, as suggested by hypothesis $\mathrm{H}_{\mathrm{D} 2}$, would contradict the Uppsala model's prediction.

Hypothesis $\mathrm{H}_{\mathrm{D} 3}$ - The Uppsala model predicts a sequential path, starting from lower commitment modes (e.g., exporting) and only later on, as the firm gains experiential knowledge, gradually moving to higher commitment modes (e.g., FDI). Hypothesis $\mathrm{H}_{\mathrm{D} 3}$, nevertheless, states that such a move to higher commitment modes might not be gradual and might even not occur at all, despite the experience (in years, not in customers) gained in the foreign market.

Hypotheses $\mathrm{H}_{\mathrm{D} 4 \mathrm{a}}$ and $\mathrm{H}_{\mathrm{D} 4 \mathrm{~b}}$ - According to the Uppsala model, the choice of level of commitment would be independent of psychic distance, i.e., firms would tend to follow a gradual path from lowerto higher-commitment modes in each country, irrespective of the psychic distance from the home country. This pattern is contradicted by both $\mathrm{H}_{\mathrm{D} 4 \mathrm{a}}$ and $\mathrm{H}_{\mathrm{D} 4 \mathrm{~b}}$. 


\section{FinAL CONSIDERATIONS}

Boddewyn, Halbrich and Perry (1986, p. 54) recommended that "specific analyses of each service sub-sector should prove more fruitful than the creation of a general category of 'service MNEs' in view of the heterogeneity of this group". Although these authors were considering "service subsectors", in this paper a different categorization of services, based on strategic dimensions and not on industry boundaries, was deemed to better reveal the characteristics of services that might influence internationalization paths and performance results. This is in accordance with Erramilli's (1990, p. 60) comment: "the entry mode options available to the manager in the same [service] industry, or even firm, could be different for different services".

This paper has cast some doubts as to whether a usually taken-for-granted assumption of the wellknown Uppsala internationalization model - that of a gradual commitment of resources in each host market - would universally apply to services. Some hypotheses were advanced as a suggestion for future studies. As Coviello and Martin (1999, p. 42) have put it, "service internationalization is too broad a concept to be defined exclusively or examined by any one theoretical framework".

Anderson and Gatignon (1986, p. 3) criticized the literature on entry mode choice for making "little direct mention to risk or return", concentrating instead on "the degree of control each mode affords the entrant". In partial response to their plea, normative hypotheses about the performance of service firms under different mode choices and moderating circumstances were advanced herein.

For the development of the theoretical reasoning and the hypotheses, it was assumed that service firms would have managerial freedom to choose from a set of distinct entry modes. Of course, in countries where government restrictions limit the choice of entry modes, the present considerations may not apply. Moreover, a desire for higher-control may not always be accompanied by a capacity to commit the necessary resources to warrant control (Erramilli \& Rao, 1993). Also the hypotheses proposed here are valid only if the service firm's objective for the particular service business under expansion is market seeking and economic return. In the case of other motivations to go international - such as resource-seeking or strategic reasons - other considerations might apply.

As a general recommendation, future researchers should be advised not to treat services as a homogeneous class. Some progress has already been made since several classification schemes have been proposed. However, although illuminating, the services typologies reviewed here may not be fully adequate to evaluate the implications of specific service characteristics for the internationalization process and the resulting (expected or observed) variation because (i) such typologies may not tap into other relevant dimensions for the internationalization decisions and (ii) there may be substantively different types of services that would be similar in a given aspect as to occupy the same categorical box in a given typology but whose differences are important as far as the internationalization path is concerned. For example, Ekeledo and Sivakumar (1998) mention Lovelock's (1983) typology, which places education (an exportable service) and psychotherapy (a non-exportable service) under the same heading - people-processing services.

Since it seems reasonable to expect that factors influencing the appropriate mode of entry will interact with one another, it is important to control for the impact of covariates in order not to overemphasize the role of some variables or to reach supposedly universal conclusions that in fact would not hold under specific circumstances. In addition, researchers should bear in mind that ceteris paribus conditions may not always be present (Hill, Hwang, \& Kim, 1990).

It should be underscored that a rejection of any null descriptive hypothesis and at the same time a failure to reject the respective null normative hypothesis may be due to the fact that the theory discussed here describes well what firms typically do, but it has not much to say about what they should do - i.e., its normative power is low. This is to say that in terms of performance it would not really make much difference whether firms behave as suggested by the theory expressed in the 
descriptive hypothesis or not. A failure to reject any of the null hypotheses may also be due to the existence of intervening (moderating or interacting) variables that were not included in the explanatory model.

The main contributions of this paper can be summarized as follows. An important assumption of the Uppsala model was challenged as far as services internationalization is concerned. Also, recognizing the complex interplay of environmental and service-specific variables, a plea for the use of multivariate, or at least bivariate, research designs was presented. Furthermore, a call for the investigation of performance implications was advocated in sharp contrast with mere descriptive accounts or implicitly taken-for-granted assumptions of the type: if firms behave as suggested by the theory they will fare better. As a final contribution, some descriptive and normative hypotheses were set forth as a suggestion for testing in future studies.

\section{REFERENCES}

Agarwal, S., \& Ramaswami, S. (1992). Choice of foreign market entry mode: impact of ownership, location and internalization factors. Journal of International Business Studies, 23(1), 1-28.

Aharoni, Y. (1966). The foreign investment decision process. Cambridge, MA: Harvard University Press.

Álavarez-Gil, M. J., Cardone-Riportella, C., Lado-Cousté, N., \& Samartín-Sáenz, M. (2003). Financial service firms' entry-mode choice and cultural diversity: Spanish companies in Latin America. The International Journal of Bank Marketing, 21(3), 109-121.

Alexander, N., \& Lockwood, A. (1996). Internationalisation: a comparison of the hotel and retail sectors. The Service Industries Journal, 16(4), 458-473.

Andersen, O. (1993). On the internationalization process of firms: a critical analysis. Journal of International Business Studies, 24(2), 209-231.

Andersen, O., \& Buvik, A. (2002). Firm's internationalization and alternative approaches to the international customer/market selection. International Business Review, 11(3), 347-363.

Anderson, E., \& Gatignon, H. (1986). Modes of foreign entry: a transaction cost analysis and propositions. Journal of International Business Studies, 17(3), 1-26.

Axinn, C., \& Matthyssens, P. (2002). Limits of internationalization theories in an unlimited world. International Marketing Review, 19(5), 436-439.

Baark, E. (1999). Engineering consultancy: an assessment of IT-enabled international delivery of services. Technology Analysis \& Strategic Management, 11(1), 55-74.

Bazerman, M. (2001). Judgment in managerial decision making (5th ed.). New York: John Wiley \& Sons.

Björkman, I. \& Forsgren, M. (2000). Nordic international business research. International Studies of Management \& Organization, 30(1), 6-25.

Boddewyn, J., Halbrich, M., \& Perry, A. (1986). Service multinationals: conceptualization, measurement and theory. Journal of International Business Studies, 17(3), 41-57.

Bouquet, C., Hebert, L., \& Delios, A. (2004). Foreign expansion in service industries: separability and human capital intensity. Journal of Business Research, 57(1), 35-42. 
Brouthers, L., Brouthers, K., \& Werner, S. (1999). Is dunning's eclectic framework descriptive or normative? Journal of International Business Studies, 30(4), 831-844.

Cardone-Riportella, C., Alvarez-Gil, M. J., Lado-Cousté, N., \& Sasi, V. (2003). The relative effects of client following and market-seeking strategies in the internationalization process of financialservice companies: a comparison of Spanish and Finnish entities. International Journal of Management, 20(3), 384-392.

Cicic, M., Patterson, P., \& Shoham, A. (1999). A conceptual model of internationalization of services firms. Journal of Global Marketing, 12(3), 81-106.

Clark, T., Rajaratnam, D., \& Smith, T. (1996). Toward a theory of international services: marketing intangibles in a world of nations. Journal of International Marketing, 4(2), 9-28.

Cloninger, P. A. (2000). The influence of service characteristics on internationalization: extending the eclectic paradigm. Unpublished PhD Dissertation. Robinson College of Business, Georgia State University, Atlanta, Georgia.

Coviello, N., \& Martin, K. (1999). Internationalization of service SMEs: an integrated perspective from the engineering consulting sector. Journal of International Marketing, 7(4), 42-66.

Cyert, R. D., \& March, S. (1963). The behavioral theory of the firm. Englewood Cliffs, New Jersey: Prentice-Hall.

Dahringer, L. (1991). Marketing services internationally: barriers and management strategies. The Journal of Services Marketing, 5(3), 5-17.

Dunning, J. (1989). Transnational corporations and the growth of services: some conceptual and theoretical issues. New York: United Nations.

Dunning, J. H., \& Kundu, S. K. (1995). The internationalization of the hotel industry - some findings from a field study. Management International Review, 35(2), 101-117.

Ekeledo, I., \& Sivakumar, K. (1998). Foreign market entry mode choice of service firms: a contingency perspective. Journal of the Academy of Marketing Science, 26(4), 274-292.

Erramilli, M. K. (1990). Entry mode choice in service industries. International Marketing Review, $7(5), 50-62$.

Erramilli, M. K. (1991). The experience factor in foreign market entry behavior of service firms. Journal of International Business Studies, 22(3), 479-501.

Erramilli, M. K. (1992). Influence of some external and internal environmental factors on foreign market entry mode in service firms. Journal of Business Research, 25(4), 263-276.

Erramilli, M. K., \& D’Souza, D. E. (1995). Uncertainty and foreign direct investment: the role of moderators. International Marketing Review, 12(3), 47-60.

Erramilli, M. K., \& Rao, C. (1990). Choice of foreign market entry modes by service firms: role of market knowledge. Management International Review, 30(2), 139-150.

Erramilli, M. K., \& Rao, C. (1993). Service firms international entry mode choice, a modified transaction-cost analysis approach. Journal of Marketing, 57(3), 19-38.

Grönroos, C. (1990). Service marketing and management. Lexington, MA: Lexington Books.

Hambrick, D. C. (1983). An empirical typology of mature industrial-product environments. Academy of Management Journal, 26(2), 213-230. 
Hill, C., Hwang, P., \& Kim, W. (1990). An eclectic theory of the choice of international entry mode. Strategic Management Journal, 11(2), 117-128.

Javalgi, R., \& White, D. (2002). Strategic challenges for the marketing of services internationally. International Marketing Review, 19(6), 563-581.

Javalgi, R. G., Griffith, D. A., \& White, D. S. (2003). An empirical examination of factors influencing the internationalization of service firms. The Journal of Services Marketing, 17(2), 185-201.

Johanson, J., \& Vahlne, J. E. (1977). The internationalization process of the firm: a model of knowledge and increasing foreign market commitment. Journal of International Business Studies, 8(1), 23-32.

Johanson, J., \& Vahlne, J. E. (1990). The mechanism of internationalisation. International Marketing Review, 7(4), 11-24.

Johanson, J., \& Wiedersheim-Paul, F. (1975). The Internationalization of the firm: four Swedish cases. Journal of Management Studies, 12(3), 305-322.

Katrishen, F. A., \& Scordis, N. A. (1998). Economies of scale in services: a study of multinational insurers. Journal of International Business Studies, 29(2), 305-324.

Klein, S., \& Roth, V. (1990). The effects of experience and psychic distance reconsidered. International Marketing Review, 7(5), 26-38.

Langhoff, T. (1997). The influence of culture differences on internationalisation processes of firms: an introduction to a semiotic and intercultural perspective. In I. Bjorkman \& M. Forsgren (Eds.). The nature of the international firm. Copenhagen: Handelshojskolens Forlag.

Lovelock, C. H. (1983). Classifying services to gain strategic marketing insights. Journal of Marketing, 47(3), 9-20.

Lovelock, C. H., \& Wright, L. (2001). Principles of service marketing and management (2nd ed.). Upper Saddle River, NJ: Prentice Hall.

Lovelock, C. H., \& Yip, G. (1996). Developing global strategies for service businesses. California Management Review, 38(2), 64-86.

March, J., \& Simon, H. (1958). Organizations. New York: John Wiley.

Mathe, H., \& Perras, C. (1994). Successful global strategies for service companies. Long Range Planning, 27(1), 36-49.

Namiki, N. (1994). Taxonomic analysis of export marketing strategy: an exploratory study of U.S. exporters of electronic products. Journal of Global Marketing, 8(1), 27-50.

Nicolaud, B. (1989). Problems and strategies in the international marketing of services. European Journal of Marketing, 23(6), 55-66.

O'Farrell, P. N., Wood, P. A., \& Zheng, J. (1996). Internationalization of business services: an interregional analysis. Regional Studies, 30(2), 101-118.

Ojala, A., \& Tyrväinen, P. (2007). Market entry and priority of small and medium-sized enterprises in the software industry: an empirical analysis of cultural distance, geographic distance, and market size. Journal of International Marketing, 15(3), 123-149.

Oviatt, B., \& McDougall, P. (1994). Toward a theory of international new ventures. Journal of International Business Studies, 25 (1), 45-64. 
Patterson, P., \& Cicic, M. (1995). A typology of service firms in international markets: an empirical investigation. Journal of International Marketing, 3(4), 57-83.

Penrose, E. T. (1959). A theory of the growth of the firm. Oxford: Basil Blackwell.

Roberts, J. (1999). The internationalization of business service firms: a stages approach. The Service Industries Journal, 19(4), 68-88.

Sanchez-Peinado, E., \& Pla-Barber, J. (2006). Un enfoque integrador de la elección del modo de entrada en los mercados internacionales: una aproximación empírica en sectores de servicios. Management International, 10(2), 43-65.

Sanchez-Peinado, E., Pla-Barber, J., \& Hébert, L. (2007). Strategic variables that influence entry mode choice in service firms. Journal of International Marketing, 15(1), 67-91.

Sharma, D., \& Johanson, J. (1987). Technical consultancy in internationalization. International Marketing Review, 4(4), 21-29.

Skaates, M. A., Tikkanen, H., \& Alajoutsijärvi, K. (2003). The international marketing of professional services projects: to what extent does territoriality matter? Journal of Services Marketing, 17(1), 83-97.

Terpstra, V., \& Yu, C. M. (1988). Determinants of foreign investment of U.S. advertising agencies. Journal of International Business Studies, 19(1), 33-46.

United Nations Conference on Trade and Development. (2004). World investment report 2004. The shift towards services. United Nations, Geneva.

United Nations Conference on Trade and Development. (2007). UNCTAD Handbook of Statistics 2007. Retrieved April 16, 2008, from http://stats.unctad.org/Handbook

Vandermerwe, S., \& Chadwick, M. (1989). The internationalization of services. The Service Industry Journal, 9(1), 79-93.

Venkatraman, N., \& Prescott, J. (1990). Environment-strategy coalignment: an empirical test of its performance implications. Strategic Management Journal, 11(1), 1-23.

World Bank. (2008). Total GDP 2006. Retrieved April 16, 2008, from http://siteresources.worldbank.org/DATASTATISTICS/Resources/GDP.pdf 